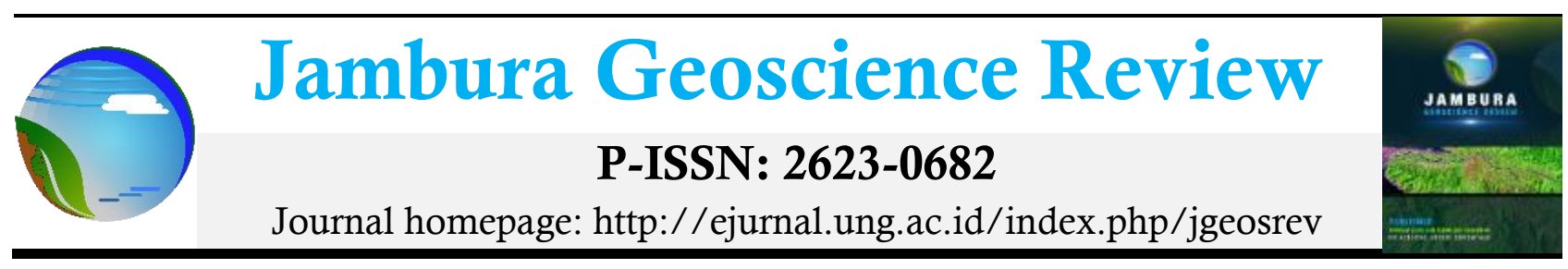

\title{
ANALISIS POTENSI WISATA BAHARI BERBASIS SISTEM INFORMASI GEOGRAFIS DI PANTAI LANGALA PROVINSI GORONTALO
}

\author{
La Ode Juni Akbar ${ }^{a}$, Daud Yusuf ${ }^{a}$, Muhammad Kasim ${ }^{a}$ \\ a Jurusan Ilmu dan Teknologi Kebumian, Fakultas Matematika dan Ilmu Pengetahuan Alam, Universitas Negeri Gorontalo \\ Jn. Jenderal Sudirman, Kota Gorontalo 96128, Indonesia
}

\section{INFO ARTIKEL}

\section{Status artikel:}

Diterima: 16 Desember 2018

Disetujui: 10 Januari 2019

Tersedia online: 31 Januari 2019

Keywords:

Map, Maritime tourisim, SIG

Penulis korespondensi:

La Ode Juni Akbar

Jurusan Ilmu dan Teknologi Kebumian,

Kota Gorontalo 96128, Indonesia

Email:

juniakbarodegeografia14@gmail.com

\begin{abstract}
The research aimed to investigate the maritime tourism potential of Langala Beach. The research was conducted in Dulupi Sub-District, Boalemo Regency, Gorontalo Province. The geographical location of the research area is $00^{\circ} 30^{\prime} 04$ "LU $-122^{0} 29^{\prime} 11^{\prime \prime}$ BT. Data is collected from primary sources and secondary sources. The research uses the triangulation data collection technique, which combines various techniques and data sources. The methods used in this study are survey methods, conformity analysis, in-depth interviews, and regional mapping. The data analysis technique focuses on the percentage assessment of tourism suitability using a marine tourism suitability index analysis for snorkeling and diving, a tourist suitability index analysis for swimming and canoeing, data analysis using the percentage of coral cover per lifeform category for the status of coral reefs. The results of the Langala Beach tourism research for marine tourism (snorkeling and diving) category included in the appropriate category (S2) with a percentage of $80.45 \%$ suitability, Langala Beach area for marine tourism category (swimming and canoeing) included in the very appropriate category (S1) with a percentage of suitability level of $93.57 \%$. The condition of coral reefs in the research location, namely station 1, is in the good category with a value of $37.12 \%$, Station 2 and 3 in the medium category with a value of $52.32 \%$ and $36.34 \%$.
\end{abstract}

Copyright (C) 2019 JGeosREV-UNG This open access article is distributed under $a$ Creative Commons Attribution (CC-BY) 4.0 International license

\section{Pendahuluan}

Pariwisata di Indonesia sangat mengalami dan memasuki era baru berskala besar dan global memberikan kontribusi nyata bagi perekonomian Indonesia. Pariwisata adalah sektor ekonomi penting bagian maritim yang menunjang pendapatan negara setelah komoditi minyak bumi, gas bumi dan minyak kelapa sawit. Kekayaan biodiversity laut seperti terumbu karang (coral reefs), mangrove, dan sea grass beds, sehingga potensial untuk pengembangan wisata terutama wisata bahari. Berkembangnya sektor pariwisata banyak menyediakan lapangan kerja sehingga mengurangi angka pengangguran. Meningkatnya industri pariwisata akan menunjang sektor-sektor lain seperti sektor pertanian, peternakan, kerajinan rakyat dan peluang kerja yang banyak. Wisata berbasis kegiatan individu atau kelompok disuatu tempat untuk refreshing, menghibur diri menikmati keindahan alam seperti keindahan suasana pantai, berselancar, mendaki gunung, berlayar, dan diving (Dahuri, et al 2001). Pengembangan kawasan wisata berbasis ekologi akan menciptakan keseimbangan antara manusia dan lingkungan sekitar sehingga kepedulian terhadap kelestarian dimiliki oleh wisatawan (Ketjulan, 2010).

Indonesia bagian timur, khususnya di Provinsi Gorontalo memiliki objek wisata yang menarik seperti wisata alam, wisata danau, wisata Religy dan wisata bahari. Secara fisiografis, Gorontalo memeliki pesisir utara dan pesisir selatan berpotensi pada sektor pariwisata salah satunya wisata bahari dan secara serius memberikan dampak positif kepada masyarakat khususnya disekitaran daerah objek wisata untuk meningkatkan pendapatan. Sebaran potensi pariwisata terdapat beberapa kawasan wisata 
di Provinsi Gorontalo yang telah dikembangkan pemerintah kabupaten/ kota, khususnya wasata bahari yaitu Taman Laut Olele, Pantai Botutonuo, Pulau Saronde, Pantai Lahilote, Pulau Bitila dan Pantai Bolihutuo termasuk Pulau Dulupi. Pesisir selatan Gorontalo khususnya Kabupaten Boalemo memiliki potensi laut dan pantai yaitu Pantai Langala yang bisa dikembangkan sebagai wisata bahari. Karakteristik wisata bahari didasarkan pada keindahan laut, terdapat hal baru yang belum kita jumpai sebelumnya, keunikan elosistem pantai dan laut sehingga wisatawan tertarik untuk menikmati wisata (Sero, 2010).

Pantai Langala merupakan salah satu pantai yang berada di Desa Tabongo, Kecamata Dulupi, Kabupaten Boalemo, Provinsi Gorontalo dengan konsisi lingkungan yang masih terjaga, dan berpotensi untuk pengembangan wisata khususnya wisata bahari. Potensi wisata mengacu pada kemampuan sebuah situs menarik dan menerima wisatawan dengan kekhawatiran tentang aksesibilitas, kualitas sumber daya, interpretasi sumber daya dan sebagainya (Anderson, 2007)

Pengembangan wisata Pantai Langala sebagai wisata bahari masih rendah karena kurangnya kontribusi pemerintah secara optimal dalam mengawal pengembangan pariwisata. Kegiatan wisata di daerah tertentu secara keseluruhan daya tarik wisata dari suatu tujuan tergantung pada hubungan antara sumber daya yang ada (alam, budaya, sejarah, dll.) dan nilai yang dirasakan dari sumber daya semacam itu (Formica, 2004).

Pengelolaan wisata pantai Langala selalu mengandalkan hasil dari swadaya masyarakat setempat. Rendahnya mutu pelayanan dari para penyelenggara pariwisata, sumber daya manusia yang rendah untuk mengelola wisata pantai, sehingganya wisatawan yang berkunjung di Pantai Langala masih minim atau masih kurang. Rendahnya sumber daya manusia yang dimiliki masyarakat dan kurangnya penelitian mengenai potensi Pantai Langala sehingganya menyulitkan pemerintah mengambil suatu kebijakan dalam mengembangkan potensi wisata Pantai Langala sebagai wisata bahari.

Wisata bahari sering dilakukan diperairan pantai adalah scuba diving, snorkling, cannoing, fishing, ski air, selancar angin dan wisata ke taman maritim (Orams, 2002), Tujuan penelitian adalah mengetahui kesesuaian kawasan wisata bahari Pantai Langala, mengetahui presentase tutupan jenis karang hidup kawasan Pantai Langala dan untuk mengetahui peta arahan pengembangan wisata bahari Pantai Langala.

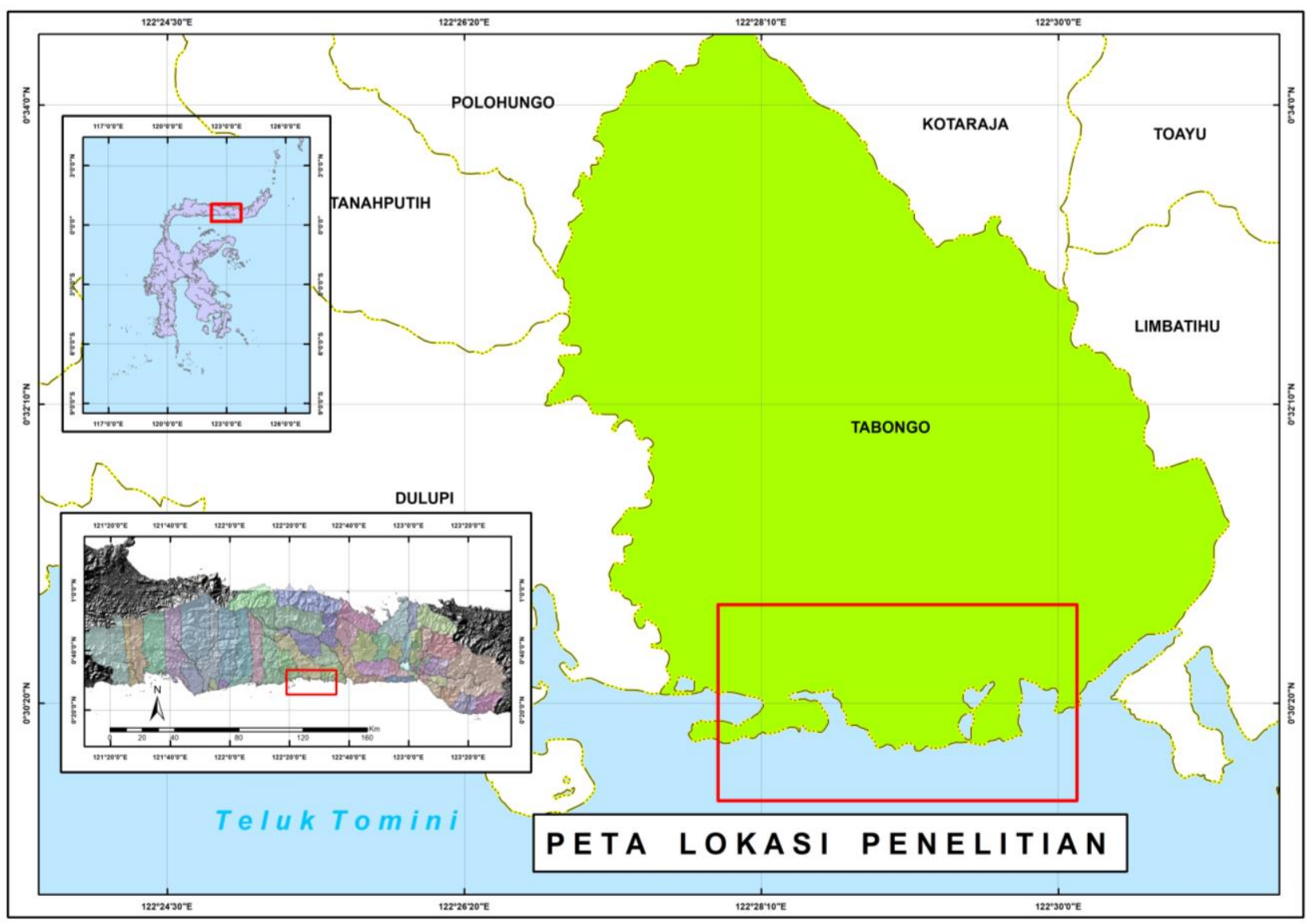

Gambar 1. Peta lokasi penelitian 


\section{Metodologi}

\subsection{Gambaran lokasi penelitian}

Penelitian dilaksanakan di Pantai Langala, Desa Tabongo, Kecamatan Dulupi, Kabupaten Boalemo Provinsi Gorontalo. Letak geografis daerah penelitian yaitu $00^{0} 30^{\prime} 04^{\prime \prime}$ LU - $122^{0} 29^{\prime} 11^{\prime \prime}$ BT. Secara administrasi sebelah utara Pantai Langala berbatasan dengan Desa Kota Raja dan Desa Polohungo Kecamatan Dulupi, sebelah timur Desa Limbatihu Kecamatan Paguyaman Pantai dan sebelah selatan Teluk Tomini, sebelah barat berbatasan dengan Desa Dulupi kecamatan Dulupi. Topologi desa yaitu perkebunan, persawahan, peternakan, nelayan dan kerajian industri kecil. Jarak dari pusat Kecamatan $0.5 \mathrm{~km}$, jarak ibu kota Kabupaten $21 \mathrm{~km}$ dan luas wilayah 80.000 ha. Peta lokasi penelitian pada Gambar 1.

\subsection{Alat dan Bahan Penelitian}

Penelitian menggunakan GPS (Global positioning Sistem), underwater meter gauge, kamera digital, underwater camera, perahu, pelampung, peralatan scuba diving, sicci disk, bahan under water paper, pensil 2b, papan polywod plastik, peta RBI Gorontalo skala 1:50.000 Tahun 1991 revisi BIG Tahun 2013 dan Citra SasPlanet 2018.

Tabel 1. Teknik pengumpulan data

\begin{tabular}{llll}
\hline No. & Jenis Data & Sumber Data & Teknik Pengumpulan Data \\
\hline 1. & Kedalaman Perairan & Primer & Pengukuran langsung dengan menggunakan Roll \\
& & meter. \\
2. & Kecerahan Perairan & Primer & Pengukuran langsung dengan menggunakan Sicci \\
& & disk. Alat tersebut dimasukkan kedalam perairan \\
& & yang diikat dengan tali sampai tidak kelihatan \\
& & kemudian dicatat sebagai kecerahan perairan.
\end{tabular}

3. Kecepatan Arus Primer Pengukuran langsung dengan menggunakan menggunakan layang-layang arus, dengan jarak tempuh arus 3 meter kemudian diukur waktu tempuh untuk mendapatkan data kecepatan arus

$\begin{array}{llll}\text { 4. } & \text { Tutupan Karang } & \text { Primer } \\ \text { 5idup } & \text { Jenis Life Form } & \text { Primer }\end{array}$
Pengukuran langsung dengan menggunakan kriteria tingkat persentase penutupan karang.

Pengukuran langsung dengan pengambilan foto terhadap dasar substrat pada frame yang terbuat dari pipa dengan ukuran panjang $100 \mathrm{~cm}$ dan lebar 100 cm (Tim Riset-Monitoring, 2006).

6. Jenis Ikan Karang Primer Dilakukan dengan pengambilan foto bawah air pada terumbu karang (Tim Riset-Monitoring, 2006).

Tabel 2. Matriks kesesuaian wisata Pantai Langala kategori wisata bahari (snorkling dan diving)

\begin{tabular}{|c|c|c|c|c|c|c|c|c|c|c|}
\hline No & Parameter & Bobot & S1 & Skor & $\mathrm{S} 2$ & Skor & S3 & Skor & $\mathrm{N}$ & Skor \\
\hline 1 & $\begin{array}{l}\text { Kecerahan } \\
\text { Perairan (Meter) }\end{array}$ & 10 & $15-20$ & 4 & $10-15$ & 3 & $5-10$ & 2 & $<5$ & 1 \\
\hline 2 & $\begin{array}{l}\text { Tutupan Terumbu } \\
\text { Karang }(\%)\end{array}$ & 9 & $>75$ & 4 & $50-75$ & 3 & $25-50$ & 2 & $<25$ & 1 \\
\hline 3 & $\begin{array}{l}\text { Jenis Terumbu } \\
\text { Karang }\end{array}$ & 8 & $>61$ & 4 & $27-61$ & 3 & $11-26$ & 2 & $<11$ & 1 \\
\hline 4 & Jenis Ikan Karang & 8 & $>61$ & 4 & $27-61$ & 3 & $11-26$ & 2 & $<11$ & 1 \\
\hline 5 & $\begin{array}{l}\text { Kecepatan Arus } \\
\text { (M/Det) }\end{array}$ & 8 & $\begin{array}{l}0- \\
0,17\end{array}$ & 4 & $\begin{array}{l}0,17- \\
0,34\end{array}$ & 3 & $\begin{array}{l}0,34- \\
0,51\end{array}$ & 2 & $<0,51$ & 1 \\
\hline \multirow[t]{2}{*}{6} & $\begin{array}{l}\text { Kedalaman } \\
\text { Perairan (Meter) }\end{array}$ & 6 & $10-25$ & 4 & $5-10$ & 3 & $2-5$ & 2 & $<2$ & 1 \\
\hline & Total & & $\mathrm{S} 1=$ & 24 & $\mathrm{~S} 2=$ & 18 & S3 $=$ & 12 & $\mathrm{~N}=$ & 6 \\
\hline
\end{tabular}

Sumber: Badan Koordinasi Survey dan Pemetaan Nasional, 1996

Ket: Kategori S1= Sangat Sesuai dengan nilai 89-94 \%; Kategori S2 = Sesuai, dengan nilai 79-88 \%; Kategori S3 = cukup Sesuai, dengan nilai 46-78\%; Kategori S4 = Tidak Sesuai, dengan nilai $<45 \%$. 


\subsection{Teknik Pengumpulan Data}

Penelitian meggunakan teknik pengumpulan data trianggulasi. Teknik pengumpulan data diartikan sebagai gabungan berbagai metode, teknik dan sumber data yang dibutuhkan pada penelitian untuk menggali informasi secara mendalam (Tabel 1). Metode penelitian ini adalah metode survei lapangan, wawancara, pemetaaan kawasan wisata bahari secara spasial dan analisis kesesuaian lahan wisata bahari. Variabel penelitian berfokus pada wisata bahari Pantai Langala (snorkling dan Diving) serta (swimming dan cannoing) (Gambar 2 dan Gambar 3).

\subsection{Teknik Analisis Data}

Analisis data yang dilakukan dalam peneltian ini berfokus pada penilaian presentase pada tingkat kesesuaian wisata kategori wisata bahari (snorkling, diving dan swimming, cannoing) (Tabel 2 dan Tabel 3). Persamaan yang digunakan untuk kesesuaian wisata pantai dan wisata bahari adalah:

$$
I K W=\sum\left(\frac{N i}{N m a k s}\right) \times 100 \%
$$

dimana: $I K W$, adalah indeks kesesuaian wisata (100\%) $N i$, adalah nilai parameteri ke-i (bobot $\mathrm{x}$ skor) dan Nmaks, adalah nilai maksimum dari suatu kategori wisata nilai (bobot $\mathrm{x}$ nilai maximal).

Persentase tutupan karang dengan menggunakan persamaan berdasarkan UNEP/AIMS, 1993 sebagai berikut:

$$
c=\sum\left[\frac{l i}{l}\right] x 100
$$

dimana: $l i$, adalah panjang karang berdasarkan bentuk pertumbuhan $(\mathrm{cm}) l$, adalah panjang garis transek (m) dan $c$, adalah persen tutupan karang (\%).

Kriteria tingkat persentase tutupan karang menurut Gomez dan Yap, (1988) dapat dilihat pada Tabel 4. Data dan informasi yang didapatkan dari survei lapangan yang sudah dianalisis kemudian dipetakan secara spasial dengan menggunakan Aplikasi SIG. Pemetaan spasial akan menentukan

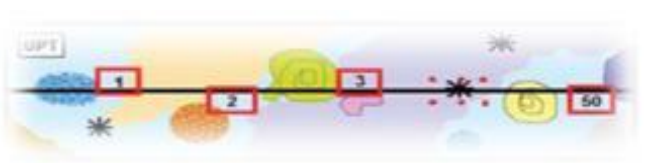

Gambar 2. Ilustrasi pengambilan sampel dengan metode Transek Foto bawah air . (Tim Riset-Monitoring, 2006)

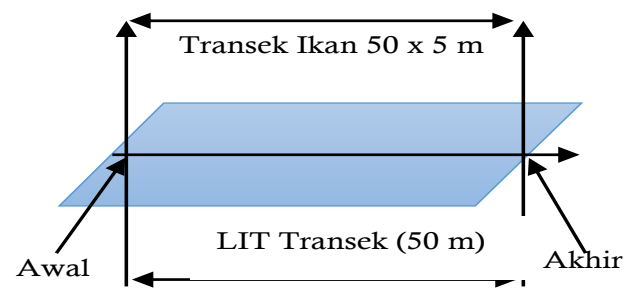

Gambar 3. Ilustrasi data sensus ikan dengan metode Transek Ikan (Tim Riset-Monitoring, 2006)

\begin{tabular}{|c|c|c|c|c|c|c|c|c|c|c|}
\hline No & Parameter & Bobot & S1 & Skor & S2 & Skor & S3 & Skor & $\mathrm{N}$ & Skor \\
\hline 1 & $\begin{array}{l}\text { Kecepatan } \\
\text { Arus (M/Det) }\end{array}$ & 10 & $0-0,17$ & 4 & $0,17-0,34$ & 3 & $\begin{array}{l}0,34- \\
0,51\end{array}$ & 2 & $>0,51$ & 1 \\
\hline 2 & $\begin{array}{l}\text { Material } \\
\text { Dasar } \\
\text { Perairan }\end{array}$ & 9 & Pasir & 4 & $\begin{array}{l}\text { Pasir } \\
\text { Sedikit } \\
\text { Karang }\end{array}$ & 3 & $\begin{array}{l}\text { Karang } \\
\text { Hidup }\end{array}$ & 2 & $\begin{array}{l}\text { Lamun } \\
+ \\
\text { Karang } \\
\text { Mati }\end{array}$ & 1 \\
\hline 3 & $\begin{array}{l}\text { Kecerahan } \\
\text { Perairan } \\
\text { (Meter) } \\
\text { Kedalaman }\end{array}$ & 8 & $10-15$ & 4 & $7-10$ & 3 & $5-7$ & 2 & $<5$ & 1 \\
\hline 4 & $\begin{array}{l}\text { Perairan } \\
\text { (Meter) }\end{array}$ & 8 & $<5$ & 4 & $6-10$ & 3 & & 2 & $>10$ & 1 \\
\hline & Total & & S1 $=$ & 16 & $\mathrm{~S} 2=$ & 12 & S3 $=$ & 8 & $\mathrm{~N}=$ & 4 \\
\hline
\end{tabular}

Tabel 3. Sistem penilaian kelayakan fisik untuk wisata bahari (swimming dan cannoing)

Sumber: Badan Koordinasi Survey dan Pemetaan Nasional, 1996

Ket: Kategori S1= Sangat Sesuai dengan nilai 89-94 \%; Kategori S2 = Sesuai, dengan nilai 79-88 \%; Kategori S3 = cukup Sesuai, dengan nilai 46-78\%; Kategori S4 = Tidak Sesuai, dengan nilai $<45 \%$. 
Tabel 4. Tabel persentase tutupan karang

\begin{tabular}{|c|c|c|c|}
\hline Parameter & \multicolumn{3}{|c|}{ Kriteria Baku Kerusakan Terumbu Karang (dalam \%) } \\
\hline \multirow{4}{*}{$\begin{array}{l}\text { Persentase Luasan } \\
\text { Tutupan Terumbu yang Hidup }\end{array}$} & \multirow{2}{*}{ Rusak } & Buruk & $0,0 \%-24,9 \%$ \\
\hline & & Sedang & $25,0 \%-49,9 \%$ \\
\hline & \multirow{2}{*}{ Baik } & Baik & $50,0 \%-74,9 \%$ \\
\hline & & Baik sekali & $75,0 \%-100 \%$ \\
\hline
\end{tabular}

Sumber: Gomez \& Yap, 1988

lokasi-lokasi yang potensial dikembangkan untuk kegiatan wisata diving, snorkling, swimming, cannoing, dan rekreasi pantai.

\section{Hasil dan Pembahasan}

Melihat dari unsur keindahan bawah laut Pantai Langala memberikan nilai tersendiri untuk dikembangkan sebagai wisata pantai dan wisata laut khususnya wisata bahari. Jenis terumbu karang yang menarik, berbagai jenis ikan karang dan biota lautnya serta panorama matahari terbenam, merupakan suatu keunggulan tersendiri yang dapat menarik wisatawan. Pantai Langala memiliki potensi keindahan, ini sudah seharusnya dikembangkan untuk menjadi salah satu ikon pariwisata di Kabupaten Boalemo menyusul pantai Boliohuto dan wisata Pulau Cinta. Hasil pengukuran lapangan dan hasil analisis garis kontur, Pantai Langala mempunya kemiringan lereng bervariasi dari datar hingga agak yaitu $0-21 \%$. Adapun kemiringan lereng pantai langala dapat dilihat pada peta kemiringan lereng (Gambar 4), mempunyai kelas relief (topografi) datar, lereng landai yakni dengan masing-masing beda ketinggian $<5$ meter, dan 5-50 meter (Gambar 5), kedalaman perairan berkisar $<1$ meter sampai 8 meter (Gambar 6) dan stasiun pengamatan penelitian (Gambar 7).

Kesesuaian kawasan wisata Pantai Langala yang diperoleh pada penelitian ini merupakan kesesuaian aktual dari pengukuran data-data di lapangan yang direpresentasikan dalam bentuk tabel penilaian masing-masing parameter. Nilai kesesuaian wisata didapatkan dari perkalian bobot dan skor masing-masing indikator setiap parameter. Kemudian nilai kesesuaian tiap parameter dikaji dalam indeks kesesuaian wisata bahari dengan skor dan masing-masing kategori.

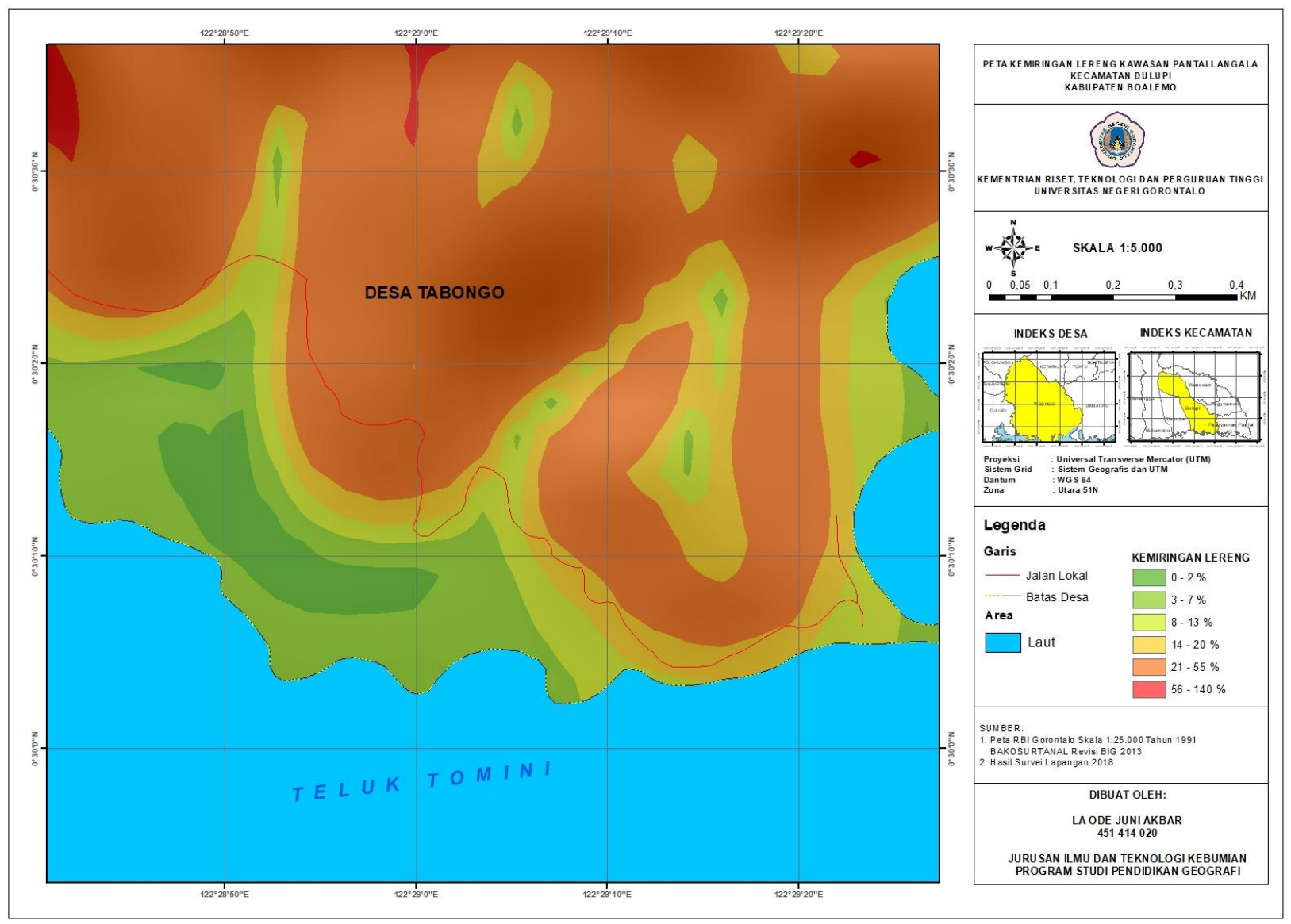

Gambar 4. Peta kemiringan lereng kawasan Pantai Langala 


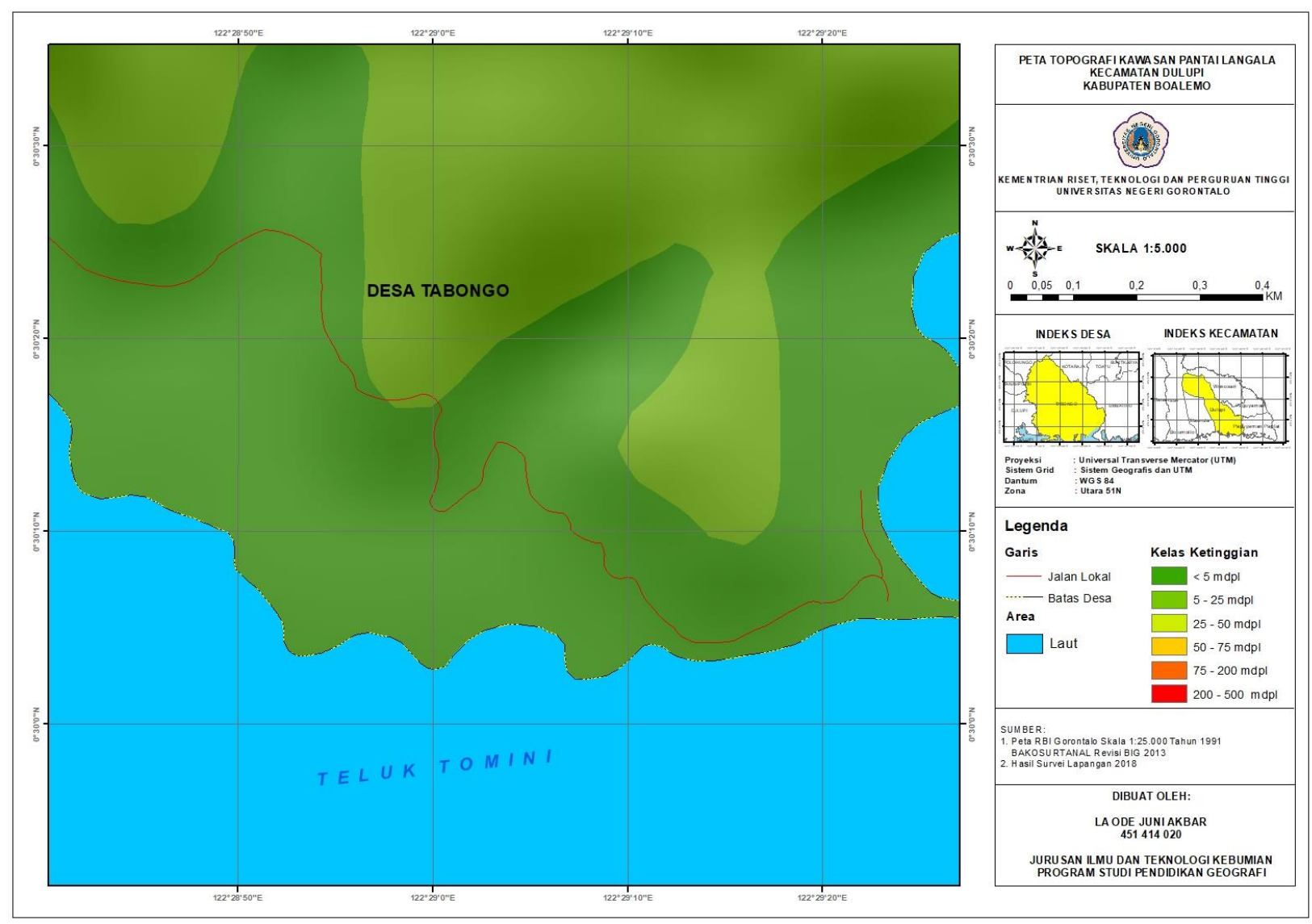

Gambar 5. Peta topografi Pantai Langala
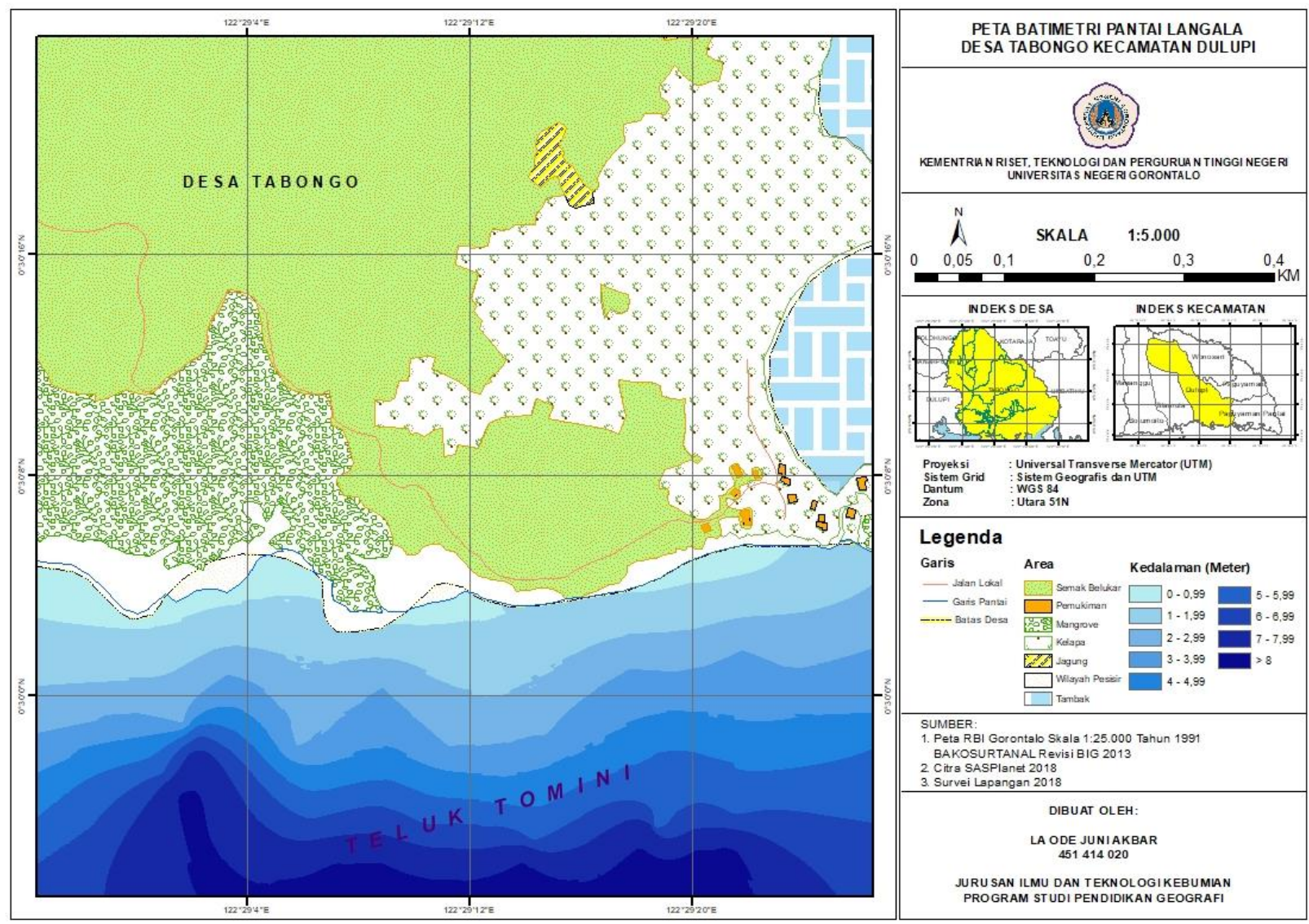

Gambar 6. Peta kedalaman perairan Pantai Langala 


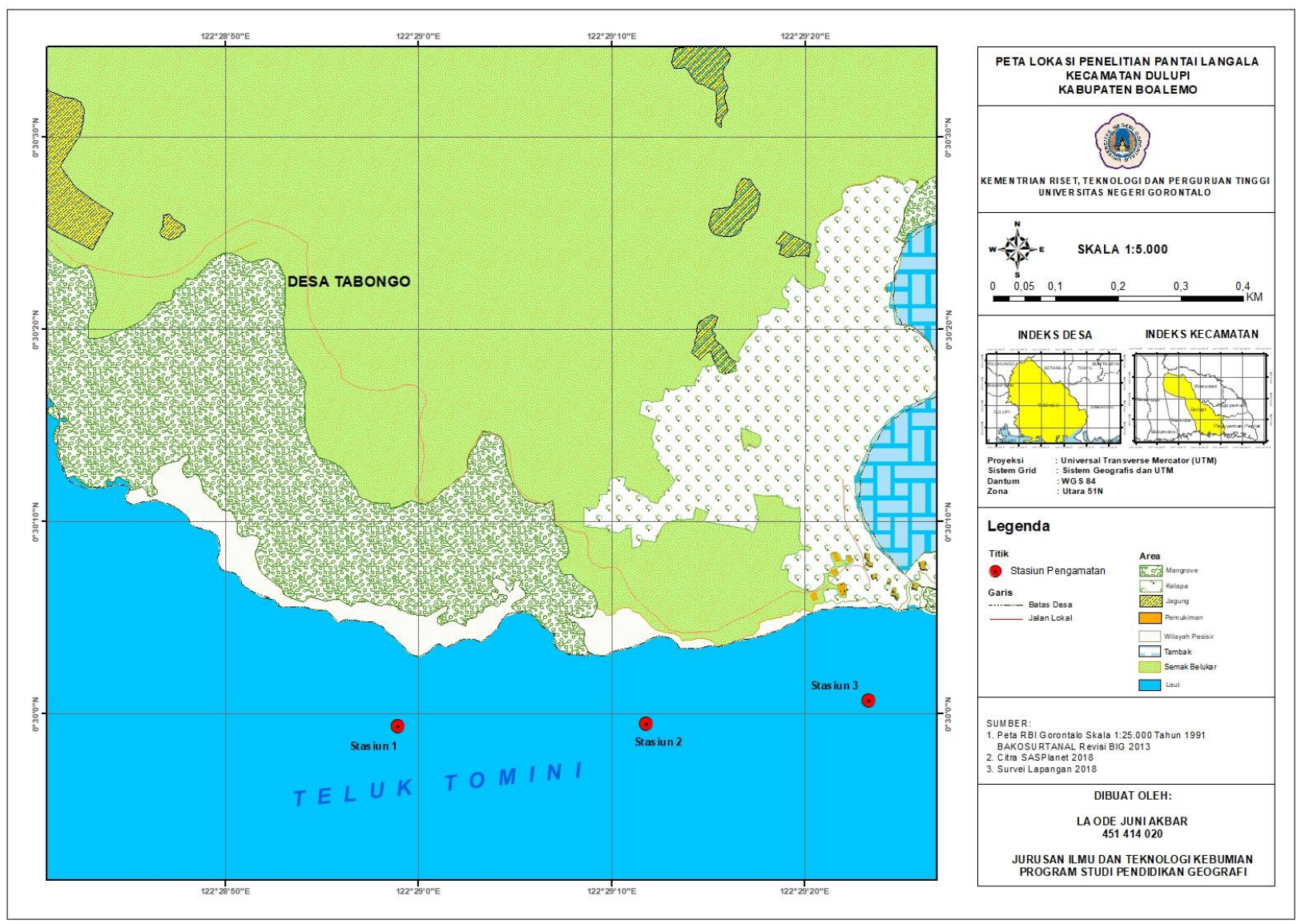

Gambar 7. Peta stasiun Pengamatan

Tabel 5. Kesesuaian wisata Pantai Langala kategori wisata bahari (snorkling dan diving)

\begin{tabular}{|c|c|c|c|c|c|c|}
\hline \multirow{2}{*}{ No } & \multirow{2}{*}{ Parameter } & \multirow{2}{*}{ Bobot } & \multicolumn{3}{|c|}{ Kategori dan Skor } & \multirow{2}{*}{ Ket. } \\
\hline & & & Kategori & Skor & Jumlah & \\
\hline 1 & Kecerahan Perairan (m) & 18 & 13.81 & 3 & 54 & S2 \\
\hline 2 & Tutupan Terumbu Karang Hidup (\%) & 9 & 52.32 & 3 & 27 & S3 \\
\hline 3 & Jenis Terumbu Karang & 8 & 29 & 3 & 24 & S2 \\
\hline 4 & Jenis Ikan Karang & 8 & Beragam & 3 & 24 & S2 \\
\hline 5 & Kedalaman Perairan (m) & 6 & $>10$ & 4 & 24 & S1 \\
\hline 6 & Kecepatan Arus (m/detik) & 6 & 0.03 & 4 & 24 & S1 \\
\hline
\end{tabular}

Hasil analisis kesesuaian Pantai Langala termasuk dalam kategori Sesuai (S2) sebesar 80,45\% untuk wisata snorkling dan diving. Analisis kesesuaian khususnya tempat yang menjadi lokasi kajian terdapat tiga lokasi untuk kegiatan penyelaman (diving) dan snorkling, yakni daerah kawasan mangrove, daerah pusat kegiatan wisata dan daerah yang dekat dengan pemukiman. Namun pada penelitian ini untuk kesesuaian wisata diving dan snorkling berfokus pada daerah pusat kegiatan wisata sedangkan untuk daerah mangrove dan pemukiman hanya sebagai pembanding dalam presentase dan kondisi terumbu karang. Hasil pengamatan pada tiga stasiun ditemukan 29 jenis terumbu karang yaitu: Acropora fastigata, Acropora millepora, Acropora monticulosa, Acropora humilis, Acropora samoensis, Acropora tenuis, Coscinaraea columna, Ctenactis echinata, Euphyllia glabrescens, Goniopora tenuidens, Heliopora coerulea, Millepora dichotoma, Pocillopora verrucosa, Pocillopora eydouxi, Pocillopora verrucosa, Porites mayeri, Porites sp, Porites lutea, Porites cylindrica, Psammocora contigua, Seriatopora hystrix, Stylophora subseriata, Symphyllia radians, Stylaster, Trachyphylliidae, Acropora palifera, Acropora yongei, Acropora hyacinthus, dan Hydnophora rigida.

Presentase tutupan karang hidup masing-masing lokasi pengamatan yaitu: $37.12 \%, 52.32 \%$ dan $36.34 \%$. Rendahnya persentase karang hidup disebabkan dari berbagai kegiatan manusia (antropogenik) dalam menangkap ikan. Misalnya penggunaan bahan peledak sebagai alat tangkap yang merusak dan 
Tabel 6. Kesesuaian Pantai Langala kategori wisata bahari (swimming dan cannoing)

\begin{tabular}{|c|c|c|c|c|c|c|}
\hline \multirow{2}{*}{ No } & \multirow{2}{*}{ Parameter } & \multirow{2}{*}{ Bobot } & \multicolumn{3}{|c|}{ Kategori dan Skor } & \multirow{2}{*}{ Ket. } \\
\hline & & & Kategori & Skor & Jumlah & \\
\hline 1 & Kecepatan Arus (m/detik) & 10 & 0.03 & 4 & 40 & S1 \\
\hline 2 & Material dasar perairan & 9 & $\begin{array}{l}\text { Pasir Sedikit } \\
\text { Karang }\end{array}$ & 3 & 27 & S2 \\
\hline 3 & Kecerahan Perairan (m) & 8 & 13.81 & 4 & 32 & S1 \\
\hline 4 & Kedalamn Perairan (m) & 8 & 2 & 4 & 32 & S1 \\
\hline
\end{tabular}
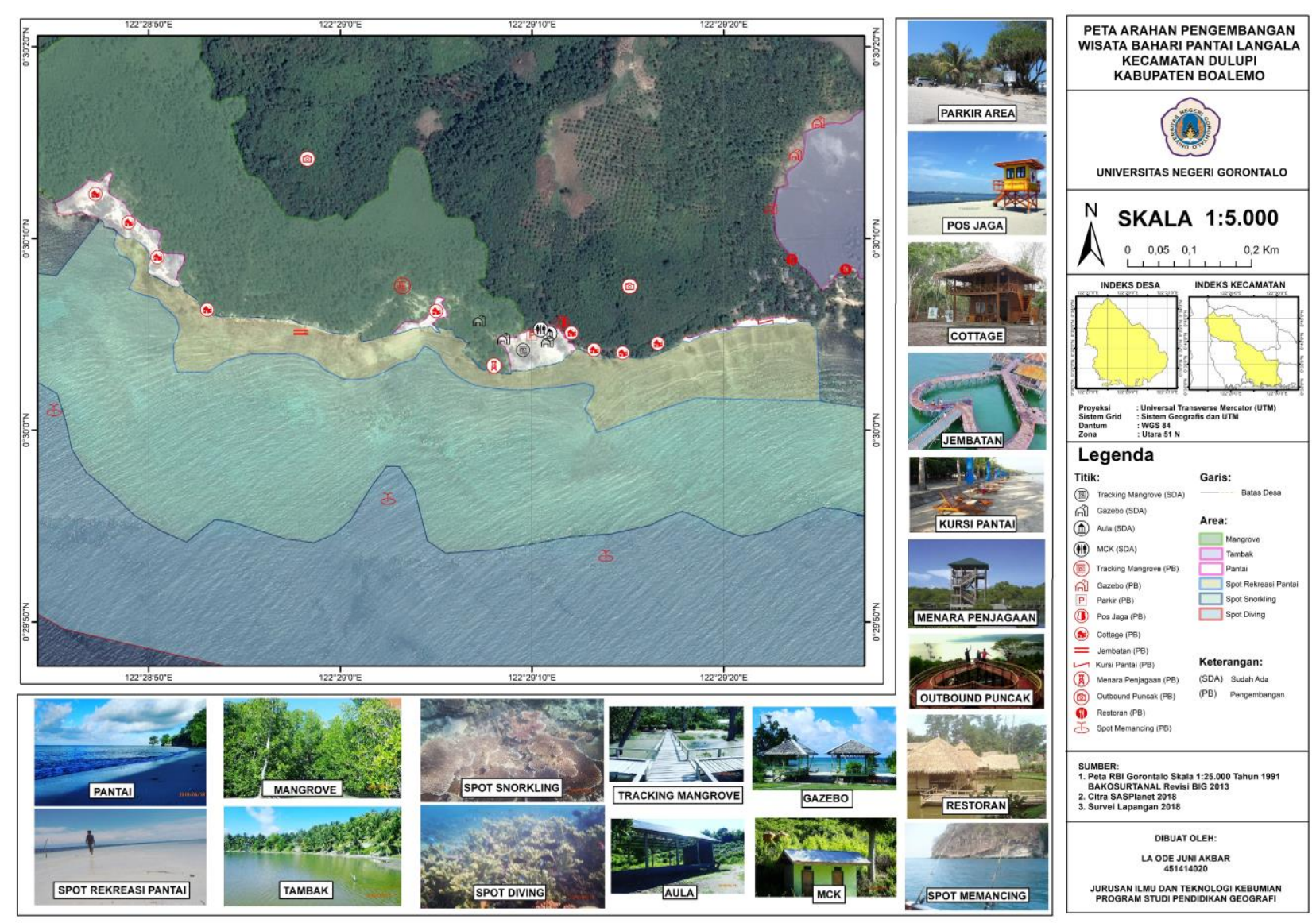

Gambar 8. Peta arahan pengembangan

pemanasan global serta terkena jangkar perahu. Berdasarkan wawancara dari salah satu nelayan menjelaskan bahwa penggunaan bahan peledak terjadi pada saat tahun 80 -an, penggunaan bahan peledak ini diduga nelayan yang berasal dari kampung-kampung jauh yang datang mengambil ikan. Kurangnya pengawasan sehingga memudahkan mereka menggunakan bahan-bahan kimia untuk mendapatkan ikan tanpa memikirkan kerusakan ekosistem terumbu karang khususnya di perairan Pantai Langala.

Berdasarkan hasil pengukuran kecepatan arus rata-rata Patai Langala $0.03 \mathrm{~m} /$ detik. Kecepatan arus perairan masuk dalam kategori sangat sesuai (S1). Kecerahan air pada ketiga stasiun pengamatan masuk dalam kategori sesuai (S2) dengan nilai kecerahan $13.81 \%-14 \%$ atau $100 \%$. Kondisi air di lokasi pengamatan jernih dan cuaca sangat cerah pada saat pengamatan berlangsung. Kedalaman terumbu karang di perairan Pantai Langala tergolong sangat sesuai (S1) yaitu pada kedalaman 3-15 m. Terumbu karang Pantai Langala termasuk dalam kategori karang dangkal karena tipe pertumbuhan karang didominasi Acropora, dan pertumbuhan masif. Dicirikan bahwa pada daerah ini sering terjadi aktivitas fisik seperti gelombang dan sedimentasi. Zonasi pada daerah ini mengalami transisi, karang bercabang tipe Acropora. Jenis yang mendominasi pada daerah ini yakni jenis masif seperti Porites. Adapun kelas kesesuaian untuk wisata bahari snorkling dan diving yaitu kelas sesuai (S2) dengan nilai $80.45 \%$ (Tabel 5). 
Hasil analisis kesesuaian Pantai Langala masuk kategori Sangat Sesuai (S2) untuk swimming dan cannoing. Jadi, analisis dari semua parameter yang mendukung menunjukan bahwa tingkat kesesuaian wisata Pantai Langala 93.57\% kategori sangat sesuai (S1) untuk dikembangkan menjadi objek wisata swimming dan cannoing (Tabel. 6). Tingginya nilai kesesuaian wisata bahari swimming dan cannoing oleh karakteristik wilayah yang khas seperti kecepatan arus yakni 0.03 meter/detik, kecerahan perairan $13.81 \%$, kedalaman perairan sebesar 2 meter. Kecepatan arus memiliki bobot yang paling tinggi yaitu 10 dibanding parameter lain karena keberadaannya dianggap paling berpengaruh untuk berlangsungnya kegiatan wisata swimming dan cannoing sekaligus menentukan kondisi perairan, tingkat kenyamanan dan keamanan wisatawan dalam melakukan aktivitasnnya. Pantai Langala memiliki kawasan pesisir dengan kondisi geooseaonografi yang berpotensi untuk dikembangkan menjadi kawasan wisata laut. Oleh karena itu, pusat kegiatan yang menguntungkan untuk ditempatkan pada kawasan tepi pantai adalah wisata bahari dan wisata pantai lainnya.

Penentuan kawasan untuk lokasi diving, snorkling, rekreasi pantai, sarana dan prasarana pendukung wisata, lokasi memancing adalah sebagai daya tarik wisatawan (Gambar 8). Berdasarkan hal tersebut tingkat kesesuaian Pantai Lagala untuk dikembangkan menjadi kawasan wisata bahari karegori swimming dan cannoing sangat sesuai (S1). Kondisi inilah, pemerintah semestinya segera mengevaluasi dan mepertimbangkan dalam perencanaan pengembangan kepariwisataan, khususnya Pantai Langala dalam pengembangan sebagai objek wisata.

\section{Kesimpulan}

Berdasarkan analis data penelitian didapatkan data indeks kesesuaian wisata pada lokasi penelitian, dapat disimpulkan bahwa kawasan wisata Pantai Langala untuk kategori wisata bahari (snorkling dan diving) termasuk dalam kategori sesuai (S2) dengan presentase tingkat kesesuaian adalah $80.45 \%$. Hasil analisis kawasan Pantai Langala untuk kategori wisata bahari (swimming dan cannoing) menunjukan bahwa prsentase tingkat kesesuaian $93.57 \%$ yaitu kategori sangat sesuai (S1). Adapun persentase tutupan karang hidup masing-masing stasiun adalah pada stasiun 1 persentase penutupan karang hidup $37.12 \%$, stasiun 2 sebesar $52.32 \%$ dan stasiun 3 yang terendah yaitu $36.34 \%$. Pantai Langala berpotensi untuk dikembangkan sebagai wisata bahari. Pengembangan wisata bahari perlunya penelitian lebih lanjut mengenai monitoring pengelolaan kawasan wisata Langala baik dari aspek Biologi, Kimia, Perikanan, sosial ekonomi dan Budaya Masyarakat.

\section{Ucapan Terima Kasih}

Ucapan terima kasih kepada Kepala Badan Perencanaan Pembangunan dan Penelitian Daerah (BAPPPEDA) Boalemo Provinsi Gorontalo yang telah berpartisipasi membantu dan mendanai penelitian serta pihak-pihak yang telah membantu sehingga penelitian dapat selesai.

\section{Referensi}

Anderson, G. (2007). The living heritage survey of the designated buffer zone of the Ukhahlamba drakensberg world heritage site. Retrieved from www.sahra.org.za.

Badan Koordinasi Survey dan Pemetaan Nasional. (1996). Pengembangan Prototip Wilayah Pesisir dan Marine Kupang Nusa Tenggara Timur. Cibinong: Pusat Bina Aplikasi inderaja dan SIG Bakosurtanal.

Dahuri, R., Rais, J., Ginting, S. P., \& Sitepu. (2001). Pengelolaan Sumber Daya Wilayah Pesisir dan Lautan Secara Terpadu. Jakarta: PT. Pradnya Paramita.

Formica, S. (2004). Destination Attractiveness As A Function of Supply And Demand Interaction. Virginia Polytechnic Institute and State University. Retrieved from https://vtechworks.lib.vt.edu/handle/10919/11273

Gomez, E. D., \& Yap, H. . (1988). Monitoring Reef Condition in Kenchington. (R. A. \& B. E. T. H. Hudson, Eds.). Jakarta: Coral Reet Management Hand Book. UNESCO Regional Office for Science and Technology for South East Asia.

Ketjulan, R. (2010). Analisis kesesuaian dan daya dukung ekowisata bahari Pulau Hari Kecamatan Laonti Kabupaten Konawe Selatan Provinsi Sulawesi Tenggara. Institut Pertanian Bogor. Retrieved from https://repository.ipb.ac.id/handle/123456789/41202

Orams, M. B. (2002). Feeding wildlife as a tourism attraction: a review of issues and impacts. Tourism Management, 23, 281-293. Retrieved from 
https://www.coastalmarineresearchgroup.com/PDFs/Orams 2002 Feeding wildlife as a tourism attraction Issues and impacts.pdf

Tim Riset-Monitoring. (2006). Manual Monitoring Kesehatan Karang (Reef Health Monitoring). Jakarta: LIPI.

Sero, A. (2010). Model pengembangan pariwisata bahari berbasis masyarakat di Kabupaten Halmahera Utara. Universitas Gadjah Mada. https://doi.org/https://doi.org/10.22146/jnp.6686

UNEP/AIMS. (1993). Monitoring Coral Reefs for Global Change. Reference Methods for Marine Pollution Studies (Vol. 61). Kenya: UNEP. 